\title{
The Effect of On-Farm Slaughter via Gunshot and Conventional Slaughter on Sensory and Objective Measures of Beef Quality Parameters
}

\author{
Markus S. Friedrich ${ }^{1}$, Katrin J. Schiffer ${ }^{2}$, Stefanie Retz ${ }^{2}$, Caroline Stehling ${ }^{1}$, Ingrid Seuß-Baum ${ }^{1} \&$ \\ Oliver Hensel ${ }^{2}$ \\ ${ }^{1}$ University of Applied Sciences Fulda, Department of Food Technology, Marquardstr. 35, 36039 Fulda, \\ Germany \\ 2 University of Kassel, Faculty of Organic Agricultural Sciences, Department of Agricultural \\ Engineering/Livestock Systems Engineering, Nordbahnhofsstraße 1a, 37213 Kassel, Germany \\ Correspondence: Markus S. Friedrich, University of Applied Sciences Fulda, Department of Food Technology, \\ Marquardstr. $\quad 35, \quad 36039$ Fulda, Germany. Tel: 49-(0)661-9640-541. E-mail: \\ Markus-Stefan.Friedrich@1t.hs-fulda.de
}

Received: October 29, 2014 Accepted: December 10, 2014 Online Published: December 15, 2014

doi:10.5539/jfr.v4n2p27 URL: http://dx.doi.org/10.5539/jfr.v4n2p27

\begin{abstract}
Beef quality parameters can be negatively affected by pre-slaughter stress. Slaughter via gunshot directly on the pasture appears to be suitable for the reduction of pre-slaughter stress by avoiding stressors such as transportation, lairage and human contact. The effect of slaughtering via gunshot on sensory and objective measures of beef quality parameters for the Musculus longissimus dorsi of Galloway steers was analyzed and compared to conventional slaughter at the abattoir using captive-bolt stunning. The Warner-Bratzler shear force (WBSF) was significantly $(\mathrm{P}<0.01)$ lower for the meat of the animals slaughtered via gunshot (arithmetic mean (AM) gunshot: $4.34 \mathrm{~kg}$; AM captive-bolt pistol: $4.77 \mathrm{~kg}$ ). However, trained assessors were not able to recognize this difference $(\mathrm{P}>0.05)$. No significant differences $(\mathrm{P}>0.05)$ were observed for cooking loss and the sensory quality evaluation of juiciness. As measured by the WBSF, the meat of the animals slaughtered via gunshot was slightly more tender than was the meat of the animals stunned with a captive-bolt pistol. However, for the cooking loss and sensory evaluations, no effect of the slaughter methods was observed. Nevertheless, this study reveals the potential that slaughter via gunshot provides for the improvement of beef quality.
\end{abstract}

Keywords: beef, pre-slaughter stress, tenderness, juiciness, sensory evaluation, Warner-Bratzler shear force

\section{Introduction}

Pre-slaughter stress, such as transportation, lairage at the abattoir and human contact, may result in an unintended deterioration of meat quality parameters, such as tenderness and juiciness, by affecting the animals' metabolic processes (Arthington, Eichert, Kunkle, \& Martin, 2003; Honkavaara, Rintasalo, Ylönen, \& Pudas, 2003; Warriss, 2003; Immonen \& Puolanne, 2000). Adverse impacts in terms of meat tenderness are particularly undesirable, as consumers can demonstrably recognize deviations and are willing to pay more for the guarantee of a tender steak (Lusk, Fox, Schroeder, Mintert, \& Koohmaraie, 2010; Wheeler, Shackelford, \& Koohmaraie, 2004; Boleman et al., 1997).

The response of animals to stressors is dependent on animal-specific genetic and epigenetic factors (Boissy, 1995). Pre-slaughter stress particularly affects animals that have not habituated to external stressors, such as animals held in year-round free range (Ferguson \& Warner, 2008; Grandin, 1997; Hastings, Abbott, George, \& Stadler, 1992). Slaughter via gunshot and bleeding directly on the pasture represents an alternative to transportation to an abattoir, stunning via captive-bolt pistol and subsequent bleeding (Council Regulation (EC) No 1099/2009).

Therefore, the objective of this study is to investigate the effects of on-farm slaughter via gunshot on beef quality parameters in comparison to captive-bolt stunning at the abattoir using both sensory and objective measures. Toward this end, the study examines whether trained assessors are able to detect instrumentally observed differences. 


\section{Experimental}

\subsection{Sensory Analysis}

\subsubsection{Panel Recruitment}

A total of 12 volunteers (6 male, 6 female), students and scientific staff of the University of Applied Sciences Fulda ranging from 21 to 32 years of age were recruited for sensory panel training sessions.

The participants were asked to fill out a questionnaire about their eating and smoking habits, age, allergies, availability and previous sensory experience. The participants who obtained training success $\geq 75 \%$ in the triangle test, the ranking test and the scaled evaluation tests were selected for the sensory panel. Thus, the panel consisted of nine panelists ( 5 male, 4 female, 22 - 32 years of age) representing trained assessors.

All participants involved in the study provided written and verbal consent, and the study was approved by the ethical committee of the University of Applied Sciences Fulda.

\subsubsection{Sample Preparation for Panel Training}

The sample preparation for the tenderness and juiciness evaluation training was based on Braghieri et al. (2012) with slight modifications (Table 1). The beef used for panel training, which was aged for 14 days (except Musculus extensor carpi radialis), was bought at a local abattoir and subsequently frozen $\left(-18{ }^{\circ} \mathrm{C}\right)$. Forty-eight hours prior to sensory training, the samples were thawed at $4{ }^{\circ} \mathrm{C}$ and cut into 1.5 -cm-thick slices perpendicular to the muscle fiber orientation. After reaching a core temperature of $6-8^{\circ} \mathrm{C}$, the slices were wrapped in aluminum foil and cooked on an SILEX electric clamshell contact-grill with smooth surfaces (S-161 K, SILEX Elektrogeräte $\mathrm{GmbH}$, Hamburg, Germany) at $220{ }^{\circ} \mathrm{C}$ until reaching the appropriate core temperature (Table 1), which was monitored by an integrated temperature sensing device. The slices were cut into cuboid shapes $(1 \mathrm{~cm}$ $\times 1 \mathrm{~cm} \times 1.5 \mathrm{~cm}$ ) and served cold.

Table 1. Sample preparation for sensory panel training

\begin{tabular}{lllllll}
\hline Attribute/ Intensity & Low & & Medium & \multicolumn{3}{l}{ High } \\
\hline & Setting* & Sample & Setting* & Sample & Setting* & Sample \\
Tenderness & $220^{\circ} \mathrm{C}^{\dagger} / 75^{\circ} \mathrm{C}$ & $E C R$ & $220^{\circ} \mathrm{C}^{\dagger} / 70^{\circ} \mathrm{C}$ & $L D$ & $220^{\circ} \mathrm{C}^{\dagger} / 53^{\circ} \mathrm{C}$ & $P M$ \\
Juiciness & $220^{\circ} \mathrm{C}^{\dagger} / 80^{\circ} \mathrm{C}^{\dagger}$ & $L D$ & $220^{\circ} \mathrm{C}^{\dagger} / 70^{\circ} \mathrm{C}$ & $L D$ & $220^{\circ} \mathrm{C}^{\dagger} / 55^{\circ} \mathrm{C}^{\dagger}$ & $L D$ \\
\hline
\end{tabular}

${ }^{*}$ Cooking temperature/core temperature. ${ }^{\dagger}$ Modified. ECR, Musculus extensor carpi radialis. LD, Musculus longissimus dorsi. PM, Musculus psoas major.

Source: Braghieri et al. (2012), modified.

\subsubsection{Panel Training}

The panel training was conducted in a standardized sensory testing room under black lighting in three hebdomadal sessions lasting approximately $1 \mathrm{~h}$ and using random three-digit codes for sample identification.

In session 1, the panelists were trained to detect tenderness and juiciness attributes by testing cubes of high, medium and low intensity for each attribute. Subsequently, the ranking and triangle tests were performed according to the ISO 8587:2006 and ISO 4120:2004 specifications (International Organization for Standardization, 2006, 2004).

In session 2, the triangle and ranking tests were repeated. Then, a scaled evaluation test was conducted. In this test, the panelists had to match a set of samples with predefined scale values of juiciness and tenderness with a set of the same samples coded with random three-digit codes. The tests were rated as "passed" when all matches were correct. The scales used were six-point semi-quantitative scales for juiciness $(6=$ excellent juiciness, $1=$ dry meat) and tenderness $(6=$ excellent tenderness, $1=$ tough meat) (Ristic, 1987). Furthermore, an evaluation test with scale using the same six-point scale was performed, in accordance with DIN 10952-1:1978 specifications (Ristic, 1987; DIN Deutsches Institut für Normung e.V., 1978).

In session 3, the scaled evaluation tests were repeated.

In general, for all sensory tests in training and evaluation, the panelists had the possibility to re-taste samples. The standards for juiciness and tenderness were served at the beginning of each session. The results were recorded using FIZZ 2.46 (Biosystèmes, Couternon, France). 


\subsubsection{Sample Preparation for Sensory Evaluation}

For this study, year-round free-range Galloway steers $(n=48)$ were obtained from an organic cattle breeding source. The steers were $30 \pm 7$ months old with a carcass weight of $206 \pm 26 \mathrm{~kg}$ and were examined over a period of six months.

The slaughter was carried out in a two-week interval. On each slaughter date, two to six animals were killed on-farm via gunshot (Retz, Schiffer, von Wenzlawowicz, \& Hensel, 2013) or slaughtered conventionally at the abattoir. Due to gunshot killing the steers' brain cannot be used for feeding or meal preparation.

A total of 23 living steers were transported for $15 \mathrm{~min}$ to a commercial abattoir. At the abattoir, the cattle were stunned via captive-bolt pistol and immediately bled. Directly on the farm, the remaining 25 steers were slaughtered via gunshot by a professional rifleman on a shooting paddock, which was integrated in the pasture and familiar to the cattle, without separating them from their herd.

A maximum of two animals from one herd were shot per date. The cattle slaughtered via gunshot were hoisted by a front loader, immediately bled and transported to the abattoir with a specially constructed trailer (T-Trailer, $3.00 \mathrm{~m} \times 1.45 \mathrm{~m} \times 1.30 \mathrm{~m}$, constructed according to Council Regulation (EC) No 853/2004, blood drain tray with drain valve, hoisting winch, for further details see ISS - Innovative Schlachtsysteme (2014)) that could carry two animals. The carcasses were chilled to $7.2 \pm 2.3{ }^{\circ} \mathrm{C}$ within $24 \mathrm{~h}$ and $4.0 \pm 1.6{ }^{\circ} \mathrm{C}$ within $48 \mathrm{~h}$ and were aged for 14 days without deboning and cutting. After aging, the M. longissimus dorsi was removed from each carcass, vacuum packaged and frozen at $-18{ }^{\circ} \mathrm{C}$ until use.

The preparation of the $M$. longissimus dorsi samples for sensory evaluation was carried out according to the sample preparation for sensory panel training (see "Sample preparation for panel training", chapter 2.1.2) except the samples were cooked to a core temperature of $70^{\circ} \mathrm{C}$.

\subsubsection{Sensory Evaluation}

The samples from cattle stunned with a captive-bolt pistol $(\mathrm{n}=17)$ and animals slaughtered via gunshot $(\mathrm{n}=18)$ were evaluated in six tasting sessions under black lighting using the evaluation test with scale and the same six-point scale used for panel training ( $6=$ excellent juiciness/tenderness, $1=$ dry/tough meat) (Ristic, 1987). In each session, four to seven samples were judged from cattle both stunned with a captive-bolt pistol and slaughtered via gunshot. All samples were served simultaneously in glass bowls using random three-digit codes for sample identification. Unsalted crackers and deionized drinking water were served for neutralization. The results were recorded using FIZZ 2.46.

\subsection{Instrumental Analysis}

\subsubsection{Warner-Bratzler Shear Force (WBSF)}

The thawing and cooking procedures were the same used for sensory panel training and sensory evaluation except the meat slices were cut to a thickness of $4.5 \mathrm{~cm}$ and cooked to a core temperature of $75^{\circ} \mathrm{C}$ (Honikel \& Blüchel, 2006).

Samples from both steers stunned with a captive-bolt pistol $(n=23)$ and steers slaughtered via gunshot $(n=25)$ were analyzed. The cooked slices wrapped in aluminum foil were stored overnight at $4{ }^{\circ} \mathrm{C}$. A total of six cores $(1.27 \mathrm{~cm} \times 1.27 \mathrm{~cm} \times 4.5 \mathrm{~cm})$ per sample were cut length parallel to the muscle fiber orientation and tempered at room temperature for $30 \mathrm{~min}$. The shear force was measured at room temperature using a texture analyzer (TA.XT plus, Stable Micro Systems, Godalming, UK; Exponent software) equipped with a $50 \mathrm{~kg}$ compression load cell and a Warner-Bratzler V-blade. Test speed was set to $4.2 \mathrm{~mm} \mathrm{~s}^{-1}$ (García-Segovia, Andrés-Bello, \& Martínez-Monzó, 2007; Liu et al., 2003). The samples were sheared perpendicular to the muscle fibers.

\subsubsection{Cooking Loss}

After thawing, the sensory session samples (prepared as described above, see "Sample preparation for panel training", chapter 2.1.2 and "Sample preparation for sensory evaluation", chapter 2.1.4) were weighed before the cooking procedure (core temperature: $6-8{ }^{\circ} \mathrm{C}$ ) utilizing a precision balance (CPA 4202S, Sartorius AG, Göttingen, Germany). After cooking, the samples were chilled at room temperature for $80 \mathrm{~min}$, freed from the adhering meat juice using paper towels and weighed again. These determinations were carried out in triplicate.

\subsection{Statistical Analysis}

The data were analyzed using IBM SPSS Statistics 20 (IBM Deutschland GmbH, Ehningen, Germany). A two-tailed Mann-Whitney U-Test was employed for statistically significant differences between populations $(\mathrm{P}<$ 0.05 ) because the data followed a non-normal distribution and/or were ordinarily scaled. 


\section{Results and Discussion}

\subsection{Tenderness Evaluation}

\subsubsection{Instrumental Evaluation}

Tenderness is considered a key factor of meat quality and consumer acceptance (Boleman et al., 1997; P. L. Brady \& Hunecke, 1985). The meat tenderness as analyzed by WBSF was found to be significantly different (P $<0.01$ ) between animals slaughtered via gunshot (arithmetic mean (AM): $4.34 \mathrm{~kg}$ ) and animals stunned with a captive-bolt pistol (AM: $4.77 \mathrm{~kg}$ ), where the samples of the animals slaughtered via gunshot were more tender (Table 2). In general, differing WBSF values might be caused by the pre-slaughter stressors, such as human contact, transportation and lairage at the abattoir, that can affect metabolic processes, as reported in numerous studies (Ferguson, Shaw, \& Stark, 2007; Arthington et al., 2003; Honkavaara et al., 2003; Warriss, 2003; Immonen \& Puolanne, 2000; Lahucky, Palanska, Mojto, Zaujec, \& Huba, 1998; Grandin, 1997).

The stressors described above were absent (transportation, lairage) or minimal (human contact) for the cattle slaughtered via gunshot in this survey.

Table 2. Arithmetic mean (AM), standard deviation (SD) and standard error of mean (SEM) values for the objective measures of gunshot steers $(n=25)$ and steers stunned with a captive-bolt pistol $(n=23)$

\begin{tabular}{|c|c|c|c|c|c|c|c|}
\hline & \multicolumn{3}{|c|}{ Gunshot } & \multicolumn{4}{|c|}{ Captive-bolt pistol } \\
\hline Attribute & $\mathrm{AM}$ & SD & SEM & $\mathrm{AM}$ & SD & SEM & Significance level \\
\hline Cooking loss $(\mathrm{g} / \mathrm{kg})$ & 242.9 & 51.7 & 6.0 & 241.8 & 51.7 & 6.2 & NS \\
\hline Warner-Bratzler shear force $(\mathrm{kg})$ & 4.34 & 1.11 & 0.09 & 4.77 & 1.31 & 0.11 & $* *$ \\
\hline Slaughter age (months) & 30.4 & 6.6 & 0.4 & 30.6 & 6.7 & 0.4 & NS \\
\hline Carcass weight (kg) & 202.1 & 26.9 & 3.1 & 210.4 & 25.0 & 3.0 & * \\
\hline
\end{tabular}

Significance: NS, not significant $(\mathrm{P}>0.05) ;{ }^{*} \mathrm{P}<0.05 ; * * \mathrm{P}<0.01$.

In addition, the pre-slaughter stress caused by transportation and lairage was very low compared to other studies and reviews reporting a distinct influence of pre-slaughter stress on metabolic processes (Ferguson \& Warner, 2008; Arthington et al., 2003; Lahucky et al., 1998).

In the current study, the animals stunned with a captive-bolt pistol were transported for 15 min. Because the abattoir specializes in emergency slaughtering and a maximum of six cattle were slaughtered per day, the lairage time was also minimal.

Significant effects of pre-slaughter stress on meat quality and metabolic processes were only observed for long lairage in groups (overnight, without food), long transportation distances and transportation periods (approximately $3 \mathrm{~h}$ ) or increased physical activity of the animals (Arthington et al., 2003; Lahucky et al., 1998; Eldridge \& Winfield, 1988).

Meat tenderness is also influenced by slaughter age (Boccard et al., 1979; Tuma, Henrickson, Odell, \& Stephens, 1963; Hiner \& Hankins, 1950; D. E. Brady, 1937). Boccard et al. (1979) reported a significant effect of animal age on the tenderness of muscles with a low collagen content from cattle aged 8 to 16 months. This effect is caused by a decrease in the collagen solubility, which leads to an increase in beef toughness. Hence, the results of the present study may be influenced by age effects. However, other studies have shown no significant aging effects on meat tenderness (Shackelford, Koohmaraie, \& Wheeler, 1995; Field, Nelms, \& Schoonover, 1966). In the present study, the age distribution in the group of animals used for the WBSF measures did not differ significantly $(\mathrm{P}>0.05)$.

Furthermore, as reported by Augustini (1987), meat tenderness can be influenced by carcass weight, depending on the daily weight gain of the animal. Because the carcass weight differed significantly $(\mathrm{P}<0.05)$ in the group of animals used for the WBSF measures in this study, an influence of carcass weight on beef tenderness may have been possible. However, this influence seems unlikely, as numerous studies confute this thesis (Huff-Lonergan et al., 2002; Beattie, Weatherup, Moss, \& Walker, 1999; Vergara, Molina, \& Gallego, 1999; Čandek-Potokar, Žlender, Lefaucheur, \& Bonneau, 1998; Crouse, Calkins, \& Seideman, 1986). In addition, contrary to the feeding procedure described by Augustini (1987), all test animals were fed identically in the present study. 
The Warner-Bratzler method itself is highly accurate, but its precision is affected by numerous factors, including coring, cooking conditions and muscle fiber orientation, which must be strictly controlled to ensure reliable and repeatable measures (Yancey, Wharton, \& Apple, 2011; McKenna, King, \& Savell, 2004; Kerth, Blair-Kerth, \& Jones, 2003; Lawrence, King, Obuz, Yancey, \& Dikeman, 2001; Wheeler, Shackelford, \& Koohmaraie, 1998; Wheeler et al., 1997; Wheeler, Shackelford, \& Koohmaraie, 1996; Szczesniak \& Torgeson, 1965; Hostetler \& Ritchey, 1964). Therefore, in the present study, the sample preparation and the WBSF measures were always performed by the same person under similar conditions.

\subsubsection{Sensory Evaluation}

Contrary to the WBSF values, the sensory evaluation of tenderness showed no significant $(\mathrm{P}>0.05)$ difference between the samples (Table 3). An existing correlation between WBSF and sensory evaluation (Wheeler et al., 2004; Otremba et al., 1999; Crouse, Cross, \& Seideman, 1985; Bouton, Harris, \& Shorthose, 1971) suggests that trained assessors are not able to identify such small differences in beef tenderness. Destefanis et al. (2008) confirmed that consumer panels can barely detect small differences in meat tenderness, as panelists were not able to clearly distinguish between the tenderness categories of "very tough" and "tough" (group range: approximately $1 \mathrm{~kg}$ ) and were inclined to rate samples as "very tender".

Table 3. Arithmetic mean (AM), standard deviation (SD) and standard error of mean (SEM) values for the sensory measures of gunshot steers $(n=18)$ and steers stunned with a captive-bolt pistol $(n=17)$

\begin{tabular}{|c|c|c|c|c|c|c|c|}
\hline & \multicolumn{3}{|c|}{ Gunshot } & \multicolumn{4}{|c|}{ Captive-bolt pistol } \\
\hline Attribute & $\mathrm{AM}$ & SD & SEM & $\mathrm{AM}$ & SD & SEM & Significance level \\
\hline Tenderness & 3.61 & 1.08 & 0.09 & 3.70 & 1.06 & 0.09 & NS \\
\hline Juiciness & 3.42 & 1.20 & 0.01 & 3.67 & 1.14 & 0.01 & NS \\
\hline Slaughter age (months) & 30.3 & 6.7 & 0.5 & 29.7 & 6.4 & 0.5 & $*$ \\
\hline Carcass weight (kg) & 204.6 & 28.4 & 5.4 & 209.0 & 26.9 & 4.8 & NS \\
\hline
\end{tabular}

Significance: NS, not significant $(\mathrm{P}>0.05) ; * \mathrm{P}<0.05 ; * * \mathrm{P}<0.01$.

Sensory scale: Minimum "1 - dry/tough meat" and maximum "6 - excellent juiciness/tenderness" (Ristic, 1987).

Moreover, the results of an evaluation by a trained consumer panel can be highly variable within the panel because the perception of tenderness may vary among panelists (Otremba et al., 1999; Zimoch \& Gullett, 1997; Brown, Langley, Martin, \& MacFie, 1994; Brown, 1994).

Because the age distribution in the group of animals used for the sensory tests was significantly different $(\mathrm{P}<$ 0.05), age effects cannot be excluded; however, this is unlikely an important factor based on the marginal differences shown in various studies (Shackelford et al., 1995; Boccard et al., 1979; Field et al., 1966; Tuma et al., 1963; Hiner \& Hankins, 1950; D. E. Brady, 1937).

\subsection{Juiciness Evaluation}

The results from the sensory evaluation and the cooking loss determination were considered in the evaluation of juiciness. Compared to tenderness, there are fewer studies investigating juiciness despite its important contribution to meat quality and flavor formation (Aaslyng, Bejerholm, Ertbjerg, Bertram, \& Andersen, 2003).

Juiciness and cooking loss correlate well for beef and pork $\left(\mathrm{R}^{2}=-0.43\right.$ to -0.79$)$ (Huff-Lonergan et al., 2002; Toscas, Shaw, \& Beilken, 1999; Wood, Nute, Fursey, \& Cuthbertson, 1995; Bouton, Ford, Harris, \& Ratcliff, 1975). In the present study, no significant differences $(P>0.05)$ were detected for sensory juiciness and cooking loss between the animals slaughtered via gunshot and the animals stunned with a captive-bolt pistol. The factors influencing the cooking loss and the juiciness are numerous and controversial (Bejerholm \& Aaslyng, 2004; Aaslyng et al., 2003; Palka \& Daun, 1999; Wood et al., 1995; Schönfeldt et al., 1993). The only commonly agreed upon factors influencing these parameters are the cooking conditions (Bejerholm \& Aaslyng, 2004; Aaslyng et al., 2003; Palka \& Daun, 1999; Wood et al., 1995; Schönfeldt et al., 1993). Because the cooking conditions did not vary in the present study, they are not expected to have influenced the differences in perceptions of juiciness. 
The group of animals used to determine the cooking loss differed significantly $(\mathrm{P}<0.05)$ in their age distribution (Table 2); however, cooking loss does not seem to be correlated with age, so an adverse effect is not anticipated (Schönfeldt et al., 1993).

Because the age distribution differed significantly $(\mathrm{P}<0.05)$ in the group of animals used for sensory evaluation (Table 3), an effect of age on sensory juiciness scoring may be possible as Schönfeldt et al. (1993) reported for goat and sheep meat, using a panel trained according to the American Meat Science Association (AMSA) guidelines for the cooking and sensory evaluation of meat. Furthermore, juiciness perception can vary among panelists, as has been reported for tenderness (Zimoch \& Gullett, 1997). Because the present study was set up as a trained consumer panel survey, these factors were considered and implemented in the planning process. For the sensory evaluation, an influence of the carcass weight on the juiciness was not expected because the carcass weights did not differ significantly $(\mathrm{P}>0.05)$ within the group of animals used. Moreover, as reported by Huff-Lonergan et al. (2002), the carcass weight was inadequately correlated with juiciness for pork.

\section{Conclusion}

The data indicate that the meat of steers slaughtered on-farm via gunshot is significantly more tender than is the meat of animals slaughtered conventionally at an abattoir with regard to the WBSF measures. However, trained assessors were not able to recognize this difference. There were no significant effects observed for the slaughter methods regarding cooking loss and sensory evaluation. Nevertheless, this study reveals the potential for slaughtering via gunshot to provide an improved quality of beef and provides a basis for further studies.

\section{Acknowledgements}

This study was funded by the Federal Office for Agriculture and Food (BLE) in Germany. The authors would also like to thank Gerd Kämmer and the staff of Bunde Wischen e.V., Roland Lausen and Dr. Uwe Richter as well as the students who joined the panel.

\section{References}

Aaslyng, M. D., Bejerholm, C., Ertbjerg, P., Bertram, H. C., \& Andersen, H. J. (2003). Cooking loss and juiciness of pork in relation to raw meat quality and cooking procedure. Food Quality and Preference, 14(4), 277-288. http://dx.doi.org/10.1016/S0950-3293(02)00086-1

Arthington, J. D., Eichert, S. D., Kunkle, W. E., \& Martin, F. G. (2003). Effect of transportation and commingling on the acute-phase protein response, growth, and feed intake of newly weaned beef calves. Journal of Animal Science, 81, 1120-1125.

Augustini, C. (1987). Einfluss produktionstechnischer Faktoren auf die Schlachtkörper- und Fleischqualität bei Rind. In Schlachtkörperqualität und Fleischqualität (Vol. 7, pp. 152-179). Kulmbach: Institut für Fleischerzeugung und Vermarktung - Bundesanstalt für Fleischforschung.

Beattie, V. E., Weatherup, R. N., Moss, B. W., \& Walker, N. (1999). The effect of increasing carcass weight of finishing boars and gilts on joint composition and meat quality. Meat Science, 52(2), 205-211. http://dx.doi.org/10.1016/S0309-1740(98)00169-7

Bejerholm, C., \& Aaslyng, M. D. (2004). The influence of cooking technique and core temperature on results of a sensory analysis of pork - depending on the raw meat quality. Food Quality and Preference, 15(1), 19-30. http://dx.doi.org/10.1016/S0950-3293(03)00018-1

Boccard, R. L., Naudé, R. T., Cronje, D. E., Smit, M. C., Venter, H. J., \& Rossouw, E. J. (1979). The influence of age, sex and breed of cattle on their muscle characteristics. Meat Science, 3(4), 261-280. http://dx.doi.org/10.1016/0309-1740(79)90003-2

Boissy, A. (1995). Fear and fearfulness in animals. Quarterly Review of Biology, 70, 165-191. http://dx.doi.org/10.1086/418981

Boleman, S. J., Bolemann, S. L., Miller, R. K., Taylor, J. F., Cross, H. R., Wheeler, T. L., ... Savell, J. W. (1997). Consumer evaluation of beef of known categories of tenderness. Journal of Animal Science, 75, 1521-1524.

Bouton, P. E., Ford, A. L., Harris, P. V., \& Ratcliff, D. (1975). Objective-Subjective Assessment of Meat $\begin{array}{lllll}\text { Tenderness. Journal of Texture } & \text { Studies, } & 6(3), & 315-328 .\end{array}$ http://dx.doi.org/10.1111/j.1745-4603.1975.tb01128.x 
Bouton, P. E., Harris, P. V., \& Shorthose, W. R. (1971). Effect of ultimate pH upon water holding capacity and tenderness of mutton. Journal of Food Science, 36(3), 435-439. http://dx.doi.org/10.1111/j.1365-2621.1971.tb06382.x

Brady, D. E. (1937). A study of the factors influencing tenderness and texture of beef. Journal of Animal Science, $30,246-250$.

Brady, P. L., \& Hunecke, M. E. (1985). Correlations of Sensory and Instrumental Evaluations of Roast Beef Texture. Journal of Food Science, 50(2), 300-303. http://dx.doi.org/10.1111/j.1365-2621.1985.tb13386.x

Braghieri, A., Piazzolla, N., Carlucci, A., Monteleone, E., Girolami, A., \& Napolitano, F. (2012). Development and validation of a quantitative frame of reference for meat sensory evaluation. Food Quality and Preference, 25(1), 63-68. http://dx.doi.org/10.1016/j.foodqual.2012.01.007

Brown, W. E. (1994). Method to Investigate Differences in Chewing Behaviour in Humans. Journal of Texture Studies, 25(1), 1-16. http://dx.doi.org/10.1111/j.1745-4603.1994.tb00751.x

Brown, W. E., Langley, K. R., Martin, A., \& MacFie, H. J. H. (1994). Characterisation of Patterns of Chewing Behaviour in Human Subjects and Their Influence on Texture Perception. Journal of Texture Studies, 25(4), 455-468. http://dx.doi.org/10.1111/j.1745-4603.1994.tb00774.x

Čandek-Potokar, M., Žlender, B., Lefaucheur, L., \& Bonneau, M. (1998). Effects of age and/or weight at slaughter on longissimus dorsi muscle: Biochemical traits and sensory quality in pigs. Meat Science, 48(3-4), 287-300. http://dx.doi.org/10.1016/S0309-1740(97)00109-5

Council Regulation (EC) No 1099/2009 (2009). Council Regulation (EC) No 1099/2009 of 24 September 2009 on the protection of animals at the time of killing, Pub. L. No. (EC) No 1099/2009.

Crouse, J. D., Calkins, C. R., \& Seideman, S. C. (1986). The Effects of Rate of Change in Body Weight on Tissue Development and Meat Quality of Youthful Bulls. Journal of Animal Science, 63, 1824-1829.

Crouse, J. D., Cross, H. R., \& Seideman, S. C. (1985). Effects of Sex Condition, Genotype, Diet and Carcass Electrical Stimulation on the Collagen Content and Palatability of Two Bovine Muscles. Journal of Animal Science, 60(5), 1228-1234.

Destefanis, G., Brugiapaglia, A., Barge, M. T., \& Dal Molin, E. (2008). Relationship between beef consumer tenderness perception and Warner-Bratzler shear force. Meat Science, 78(3), 153-156. http://dx.doi.org/10.1016/j.meatsci.2007.05.031

DIN Deutsches Institut für Normung e.V. (1978). DIN 10952-1 1978 - Sensory testing methods; evaluation test with scale, testing method. Berlin: Beuth Verlag.

Eldridge, G., \& Winfield, C. (1988). The behaviour and bruising of cattle during transport at different space allowances. Australian Journal of Experimental Agriculture, 28(6), 695-698. http://dx.doi.org/10.1071/EA9880695

Ferguson, D. M., Shaw, F. D., \& Stark, J. L. (2007). Effect of reduced lairage duration on beef quality. Australian Journal of Experimental Agriculture, 47(7), 770-773. http://dx.doi.org/10.1071/EA05212

Ferguson, D. M., \& Warner, R. D. (2008). Have we underestimated the impact of pre-slaughter stress on meat quality in ruminants? Meat Science, 80(1), 12-19. http://dx.doi.org/10.1016/j.meatsci.2008.05.004

Field, R. A., Nelms, G. E., \& Schoonover, C. O. (1966). Effects of Age, Marbling and Sex on Palatability of Beef. Journal of Animal Science, 25(2), 360-366.

García-Segovia, P., Andrés-Bello, A., \& Martínez-Monzó, J. (2007). Effect of cooking method on mechanical properties, color and structure of beef muscle (M. pectoralis). Journal of Food Engineering, 80(3), 813-821. http://dx.doi.org/10.1016/j.jfoodeng.2006.07.010

Grandin, T. (1997). Assessment of stress during handling and transport. Journal of Animal Science, 75(1), 249-257.

Hastings, B. E., Abbott, D. E., George, L. M., \& Stadler, S. G. (1992). Stress factors influencing plasma cortisol levels and adrenal weights in Chinese water deer (Hydropotes inermis). Research in Veterinary Science, 53(3), 375-380. http://dx.doi.org/10.1016/0034-5288(92)90143-P

Hiner, R. L., \& Hankins, O. G. (1950). The Tenderness of Beef in Relation to Different Muscles and Age in the Animal. Journal of Animal Science, 9(3), 347-353. 
Honikel, K. O., \& Blüchel, E. (2006). Apparative Messung der Zartheit von Fleisch. In Handbuch der chemischen und physikalischen Fleisch- und Fleischwarenanalyse (Vol. 19, pp. 291-295). Kulmbach: Institut für Fleischerzeugung und Vermarktung - Bundesanstalt für Fleischforschung.

Honkavaara, M., Rintasalo, E., Ylönen, J., \& Pudas, T. (2003). Meat quality and transport stress of cattle. Deutsche Tierärztliche Wochenschrift, 110(3), 125-128.

Hostetler, R. L., \& Ritchey, S. J. (1964). Effect of Coring Methods on Shear Values Determined by Warner-Bratzler Shear. Journal of Food Science, 29(5), 681-685. http://dx.doi.org/10.1111/j.1365-2621.1964.tb00431.x

Huff-Lonergan, E., Baas, T. J., Malek, M., Dekkers, J. C. M., Prusa, K., \& Rothschild, M. F. (2002). Correlations among selected pork quality traits. Journal of Animal Science, 80(3), 617-627.

Immonen, K., \& Puolanne, E. (2000). Variation of residual glycogen-glucose concentration at ultimate pH values below 5.75. Meat Science, 55(3), 279-283. http://dx.doi.org/10.1016/S0309-1740(99)00152-7

International Organization for Standardization. (2004). Sensory analysis - Methodology: triangle test - ISO 4120:2004.

International Organization for Standardization. (2006). Sensory analysis - Methodology: ranking - ISO 8587:2006.

ISS - Innovative Schlachtsysteme. (2014). Der T-Trailer. Retrieved from http://www.innovative-schlachtsysteme.de/DER-T-TRAILER.html

Kerth, C. R., Blair-Kerth, L. K., \& Jones, W. R. (2003). Warner-Bratzler Shear Force Repeatability in Beef Longissimus Steaks Cooked With a Convection Oven, Broiler, or Clam-shell Grill. Journal of Food Science, 68(2), 668-669. http://dx.doi.org/10.1111/j.1365-2621.2003.tb05729.x

Lahucky, R., Palanska, O., Mojto, J., Zaujec, K., \& Huba, J. (1998). Effect of preslaughter handling on muscle glycogen level and selected meat quality traits in beef. Meat Science, 50(3), 389-393. http://dx.doi.org/10.1016/S0309-1740(98)00042-4

Lawrence, T. E., King, D. A., Obuz, E., Yancey, E. J., \& Dikeman, M. E. (2001). Evaluation of electric belt grill, forced-air convection oven, and electric broiler cookery methods for beef tenderness research. Meat Science, 58(3), 239-246. http://dx.doi.org/10.1016/S0309-1740(00)00159-5

Liu, Y., Lyon, B. G., Windham, W. R., Realini, C. E., Pringle, T. D. D., \& Duckett, S. (2003). Prediction of color, texture, and sensory characteristics of beef steaks by visible and near infrared reflectance spectroscopy. A feasibility study. Meat Science, 65(3), 1107-1115. http://dx.doi.org/10.1016/S0309-1740(02)00328-5

Lusk, J., Fox, J., Schroeder, T. C., Mintert, J., \& Koohmaraie, M. (2010). Will Consumers Pay for Guaranteed Tender Steak? Retrieved from http://krex.ksu.edu/dspace/handle/2097/2608

McKenna, D. R., King, D. A., \& Savell, J. W. (2004). Comparison of clam-shell cookers and electric broilers and their effects on cooking traits and repeatability of Warner-Bratzler shear force values. Meat Science, 66(1), 225-229. http://dx.doi.org/10.1016/S0309-1740(03)00095-0

Otremba, M. M., Dikeman, M. E., Milliken, G. A., Stroda, S. L., Unruh, J. A., \& Chambers, E. (1999). Interrelationships among evaluations of beef longissimus and semitendinosus muscle tenderness by Warner-Bratzler shear force, a descriptive-texture profile sensory panel, and a descriptive attribute sensory panel. Journal of Animal Science, 77(4), 865-873.

Palka, K., \& Daun, H. (1999). Changes in texture, cooking losses, and myofibrillar structure of bovine M. $\begin{array}{lllll}\text { semitendinosus during } & \text { 237-243. }\end{array}$ http://dx.doi.org/10.1016/S0309-1740(98)00119-3

Retz, S., Schiffer, K. J., von Wenzlawowicz, M., \& Hensel, O. (2013). Stress-free slaughter of pasture beef First results of a pilot project, Tierärztliche Umschau, 68, 242-243.

Ristic, M. (1987). Genusswert von Rindfleisch. In Schlachtkörperqualität und Fleischqualität (Vol. 7, pp. 207-234). Kulmbach: Institut für Fleischerzeugung und Vermarktung - Bundesanstalt für Fleischforschung.

Schönfeldt, H. C., Naudé, R. T., Bok, W., van Heerden, S. M., Sowden, L., \& Boshoff, E. (1993). Cooking- and juiciness-related quality characteristics of goat and sheep meat. Meat Science, 34(3), 381-394. http://dx.doi.org/10.1016/0309-1740(93)90085-V 
Shackelford, S. D., Koohmaraie, M., \& Wheeler, T. L. (1995). Effects of slaughter age on meat tenderness and USDA carcass maturity scores of beef females. Journal of Animal Science, 73(11), 3304-3309.

Szczesniak, A. S., \& Torgeson, K. W. (1965). Methods of meat texture measurement viewed from the background of factors affecting tenderness. Advances in Food Research, 14, 33-165. http://dx.doi.org/10.1016/S0065-2628(08)60148-2

Toscas, P. J., Shaw, F. D., \& Beilken, S. L. (1999). Partial least squares (PLS) regression for the analysis of instrument measurements and sensory meat quality data. Meat Science, 52(2), 173-178. http://dx.doi.org/10.1016/S0309-1740(98)00165-X

Tuma, H. J., Henrickson, R. L., Odell, G. V., \& Stephens, D. F. (1963). Variation in the Physical and Chemical Characteristics of the Longissimus Dorsi Muscle from Animals Differing in Age. Journal of Animal Science, 22(2), 354-357.

Vergara, H., Molina, A., \& Gallego, L. (1999). Influence of sex and slaughter weight on carcass and meat quality in light and medium weight lambs produced in intensive systems. Meat Science, 52(2), 221-226. http://dx.doi.org/10.1016/S0309-1740(98)00171-5

Warriss, P. D. (2003). Optimal lairage times and conditions for slaughter pigs: a review. Veterinary Record, 153(6), 170-176. http://dx.doi.org/10.1136/vr.153.6.170

Wheeler, T. L., Shackelford, S. D., Johnson, L. P., Miller, M. F., Miller, R. K., \& Koohmaraie, M. (1997). A comparison of Warner-Bratzler shear force assessment within and among institutions. Journal of Animal Science, 75(9), 2423-2432.

Wheeler, T. L., Shackelford, S. D., \& Koohmaraie, M. (1996). Sampling, cooking, and coring effects on Warner-Bratzler shear force values in beef. Journal of Animal Science, 74(7), 1553-1562.

Wheeler, T. L., Shackelford, S. D., \& Koohmaraie, M. (1998). Cooking and palatability traits of beef longissimus steaks cooked with a belt grill or an open hearth electric broiler. Journal of Animal Science, 76(11), 2805-2810.

Wheeler, T. L., Shackelford, S. D., \& Koohmaraie, M. (2004). The accuracy and repeatability of untrained laboratory consumer panelists in detecting differences in beef longissimus tenderness. Journal of Animal Science, 82, 557-562.

Wood, J. D., Nute, G. R., Fursey, G. A. J., \& Cuthbertson, A. (1995). The effect of cooking conditions on the eating quality of pork. Meat Science, 40(2), 127-135. http://dx.doi.org/10.1016/0309-1740(94)00051-8

Yancey, J. W. S., Wharton, M. D., \& Apple, J. K. (2011). Cookery method and end-point temperature can affect the Warner-Bratzler shear force, cooking loss, and internal cooked color of beef longissimus steaks. Meat Science, 88(1), 1-7. http://dx.doi.org/10.1016/j.meatsci.2010.11.020

Zimoch, J., \& Gullett, E. A. (1997). Temporal aspects of perception of juiciness and tenderness of beef. Food Quality and Preference, 8(3), 203-211. http://dx.doi.org/10.1016/S0950-3293(96)00049-3

\section{Copyrights}

Copyright for this article is retained by the author(s), with first publication rights granted to the journal.

This is an open-access article distributed under the terms and conditions of the Creative Commons Attribution license (http://creativecommons.org/licenses/by/3.0/). 